International Journal of English Literature and Social Sciences
Vol-6, Issue-4; Jul-Aug, 2021
Journal Home Page Available: $\underline{\text { https://ijels.com/ }}$ Journal DOI: $10.22161 /$ ijels

Peer-Reviewed Journal

\title{
Mareraosan Tradition in Bali Traditional Marriage Rituals
}

\author{
Gek Diah Desi Sentana, I WayanCika, I Nyoman Suarka, I Nyomanweda Kusuma
}

Received: 09 Jul 2021; Received in revised form: 11 Aug 2021; Accepted: 22 Aug 2021; Available online: 01 Sep 2021

(C)2021 The Author(s). Published by Infogain Publication. This is an open access article under the CC BY license

(https://creativecommons.org/licenses/by/4.0/).

\begin{abstract}
The Mareraosan oral tradition is a tradition of word of mouth, which is very unique because it includes literary, religious, local wisdom, ethics and aesthetic abilities. This oral tradition can develop and exist because it is supported by the supporters themselves, meaning that there are always people who want to preserve the tradition. Aspects of marriage that include the rights and obligations of the bride and groom are spoken directly by the dragoman(jururaos). Jururaos is the person chosen by the family to give advice to the bride and groom.

The theory used in this research is the theory of socio cultural action from Max Weber which includes actions that are directed rationally, actions based on values, actions based on emotions and actions based on culture. The main finding in this study is that the oral tradition of mareraosanis a medium for delivering messages from parents and community leaders to the bride and groom. In the mareraosan tradition, there are also three main witnesses (Tri Upasaksi), namely, the witness god, the witness human, and the witness bhuta. This is what distinguishes the mareraosantradition from other marriage traditions.
\end{abstract}

Keywords-marriage, Balinese custom, oral tradition, mareraosan.

\section{INTRODUCTION}

Oral tradition is defined as all spoken discourse including spoken and scripted (Pudentia, 2015: 3). One of the oral traditions that are part of local wisdom and is found in almost all areas of Bali is the mareraosantradition. This mareraosan tradition is a series of pawiwahan or marriage ceremonies. This tradition takes place when the groom comes to the bride's house to ask for the blessing of the bride's parents. This tradition does not only involve the family, but also traditional officers or traditional leaders from the place where the bride and groom are domiciled.

According to religious leaders, the mareraosan tradition has been known since ancient times where at that time mareraosan was used as a symbol of blessing from parents and the ability of the bride and groom to marry. In the view of philosophy (tattwa), the blessing of parents and society for the continuation of the marriage can lead the bride and groom to happiness or peace. It all depends on the good intentions of both parties. So that in this tradition aspects of the marriage of GrahastaAsrama are important things to be instilled by parents and understood by the bride and groom which will be conveyed in the form of speech through the mareraosantradition.

If we trace the mareraosan tradition, it turns out that in fact it is not only a complex and amazing cultural heritage, but more than that. The mareraosan tradition holds many philosophies of life that are very useful for human life and can be used as a way of life in fostering social life. The formation of a noble personality and character for the Indonesian people in general and the Balinese people in particular can also be seen in the mareraosan tradition itself. With regard to the aspects of marriage in Balinese custom called GrahastaAsrama, the mareraosan tradition is one of the media to instill these values.

The mareraosan tradition is a form of tradition used by the media to convey advice or talk about stories related to building a harmonious household, delivered in common language in each session. The mareraosan tradition introduces the bride and groom to epics such as the Mahabharata and the Ramayana which contain moral 
messages, and will provide good advice that should be imitated through the GrahastaAsrama of the characters embodied in the form of mareraosan as a mirror in living life.But along with the times, this tradition which initially required a fairly long duration is now starting to be shortened. But this actually made the traditional leaders and parents not have time to give advice about the life of GrahastaAsramato the bride and groom. The cultivation of the concept of GrahastaAsrama is very important for the bride who was previously single and will now enter the marriage stage, considering that married life is very different because it will be related to the families of both parties and the community.

\section{METHOD}

This research is a qualitative research using a socio-cultural approach. The data collection method begins with observation, interviews, documentation and literature study. The theory used is the theory of socio-cultural action from Max Weber. Max Weber made a classification of socio-cultural changes or socio-cultural actions into 4, namely: 1) rationally directed behavior, 2) value-oriented behavior, 3) behavior that accepts orientation from feelings or emotions or affective, and 4) traditional behavior. Can be said as an action that takes into account cultural and societal considerations (Turner, 2012: 113).

\section{DISCUSSION}

Each ceremony certainly has a function for those who carry out the ceremony, as a human created by God will feel a vibration of trust to carry out a ceremony, so that by carrying out the ceremony can increase the belief to convey a sense of devotion. In general, Hindu rituals are aimed at gaining inner and outer prosperity, asking for blessings and safety from Ida Sang HyangWidhiWasa. For this, it is necessary to have a manusayadnya, namely upakara-upakarayadnya from the time humans are in the womb until the time they return to the niskala realm (Surayin, 2004: 1).

The wedding ceremony is one part of the yadnya human ceremony that should be carried out by Hindus. It can be understood that the marriage ceremony is an important ceremony in the life of Hindus, because it means removing dirt (nyupat) so as to find the true nature of human beings and be released from the shackles of darkness due to the influence of Sad Ripu in humans. The implementation of the mareraosan tradition is carried out based on the teachings of Hinduism, in its general scope it has carried out the teachings of the three framework (Tri KerangkaDasar) of Hinduism, namely tattwa, susila and upakara.

Marriage tradition in Bali states that the validity of a marriage must go through the mareraosan oral tradition. Wherever the marriage is carried out, if it has not carried out the mareraosan tradition, the marriage is considered invalid even though it is carried out by Sang Sulinggih, even though it will not be valid because it is not witnessed by traditional prajuru and not through thejururaos.

In the implementation of the mareraosan oral tradition, there are facilities for bantenpejati and lembaran, canangpanyapa, base, pamor, mako, roko, which contain philosophy. The word 'sapa' in panyapacomes from the word 'sapa' which means to greet. In this case, bantenpejati is a means to get closer to or connect with Ida Sang HyangWidhiWasa as the ruler of this world and as a regulator of everything that moves (spirited) and that which does not move (soulless). Banten serves to ask for the safety of marriages that have been carried out by its people so that they are awarded eternity and eternity as husband and wife for life. While the banten in the mareraosan ceremony is always placed side by side because as a symbol of purusa and pradana or men and women who are expected later in carrying out the household period to always be side by side in joy and sorrow because this bantenpejati also consists of tumpeng and soda. Tumpeng symbolizes men and soda represents women. Behavior that is directed rationally to the achievement of a goal such as Weber's theory can be seen in the oral tradition of mareraosan. In other words, it can be said as a match between means and ends. For example, a married couple respects each other and works hard to earn a sufficient living, thus creating a prosperous family.

Value oriented behavioralso available in mareraosan oral tradition. In relation to basic values in society, the values here are brotherhood, and hard work. Planting the concept of marriage or GrahastaAsrama, we see couples who come from various circles mingling with family and society without discriminating. 


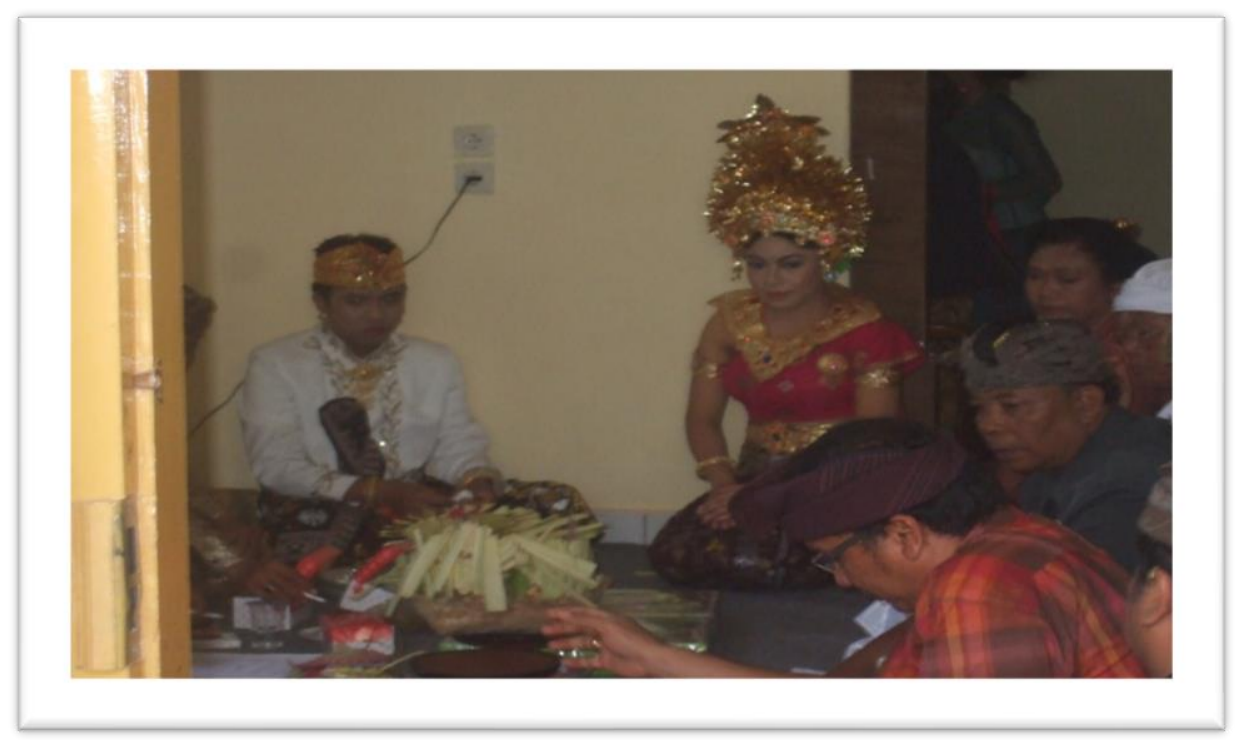

Photo.3.1 Mareraosan tradition in Balinese traditional wedding rituals

GekDiahDesiSentana's Personal Documentation (2017)

The photo above provides an overview of the mareraosan tradition where parents give advice so that the bride and groom are able to control their feelings or emotions or affectively during marriage. Every religion in Indonesia has ethics or morals that are believed to be true as guidelines for living in everyday life. Ethics means the rules of good and noble behavior that must be a guide for human life. The speech given to the groom is as follows.

cening, swadarmaning sane mebuat tuah patut ngeruruh pengupa jiwa, apang ada anggon ngemertanin raga, somah, miwah pianak. Kekalih, sayaga teken pidabdabe mesima karma (bermasyarakat). Yan suba nyama braya makejang pada tresna sih, ento anggon kesugihan ane pinih utama. Sane kaping tiga, bakti teken sang Guru Rupaka (Meme Bapa), keto masih teken matua apang patuh sekadi guru rupaka pagelahan.

Translate

My son, the most important obligation as the head of the family is to earn a living, so that it can be used to support myself, my wife, and children. Second, must be ready to live in society. If you are married and live in love, that is the most important wealth. Third, be filial to your parents as well as your in-laws. Treat your in-laws like your own parents.
Oral speech in the form of advice is not only conveyed to the groom but also to the bride. As for advice to the bride as contained in the quote below.

Cening ayu, mawinan dados mesikian mepikuren janten sampun sangkaning tresna sane janten sampun ketiba ring sang alaki. Pemekas nyandang limbakang tresnane punika mantuka ring matua, ipah, saha sane tios-tiosan. Taler tan dados lali ring Aji Biyang (Bapa Meme) maka guru rupaka yadiastun pacang metinggal saking natah iriki riantuk tan sida pacang naur kepiutangan ring rerama.Kekalih, kasih sayang ring kurenan patut kedulurin antuk patibrata inggih punika nuut ring kurenan tur satya.

Translate:

My daughter, the cause of this marriage must be because of the love for the husband. You should also love your in-laws, in-laws, and other family members. But don't forget mom and dad as biological parents, even though they won't be living in this house anymore. Because until whenever a child will not be able to pay debts to parents. Second, as a wife, love for her husband must be shown by obeying her husband's words, and being faithful.

The above advice given during the oral tradition of mareraosan, is entirely a teaching on how to behave as husband and wife. Mantra (2013: 5) states that morals are rules of behavior to foster human character to 
be good and noble. Good and noble human character can be fostered starting from family, community, and school life so that they become human beings who have good personalities and are accepted by their environment. Humans who are born in the world to be accepted by their environment, others and in worshiping God should always try to do good and right. In the book Sarasamuscayasloka 2 described:

\section{Manusasarvabhutesu. \\ Varttetevaicubhachube \\ Acubehesusamawistam \\ cubheswawewakarayet.}

Translate:

Out of so many living creatures,

who were born as humans alone, that can do good and bad;

As for the fusion of bad deeds into good deeds, there are also benefits for being human.

Traditional behavior is said to be an action that takes into account cultural and community considerations. The oral tradition of mareraosanis carried out by the Balinese people to preserve ancestral culture. Aspects of marriage related to social functions are found in the existence of Tri Upasaksiwho always go hand in hand with one another and cannot be separated in every Hindu religious ceremony in Bali. What is meant by tri upasaksiis manusasaksi,bhutasaksi, and dewasaksi. Manusasaksi are human witnesses, in this case parents, traditional leaders, Banjar people who are witnesses in a marriage. The meeting of the bride's family with the jururaosand village prajuru will discuss matters of marriage as well as provide advice to the bride and groom.

Bhutasaksi are witnesses of the universe and its contents. As for the ritual that is presented to Bhuta, the witness is to offer segehan, durmanggala and byakala. UpakaraBhutasaksi are presented at the ceremony, and under the pejati which is placed in front of the jururaos, so that the ceremony goes as expected. This ritual is a symbol of a request to the bhutakala, so as not to get hit by obstacles.

The main thing is the existence of a dewasaksi. The dewasaksi are the gods and ancestors who witness the course of a marriage ceremony. The ritual ingredients consist of bantenpejati. In this case, bantenpejati is a means to get closer to or connect with Ida Sang HyangWidhiWasa as the ruler of this world and as a regulator of everything that moves (spirited) and that which does not move (soulless). Bantenserves to ask for the safety of marriages that have been carried out by its people so that they are awarded eternity and eternity as husband and wife for life.

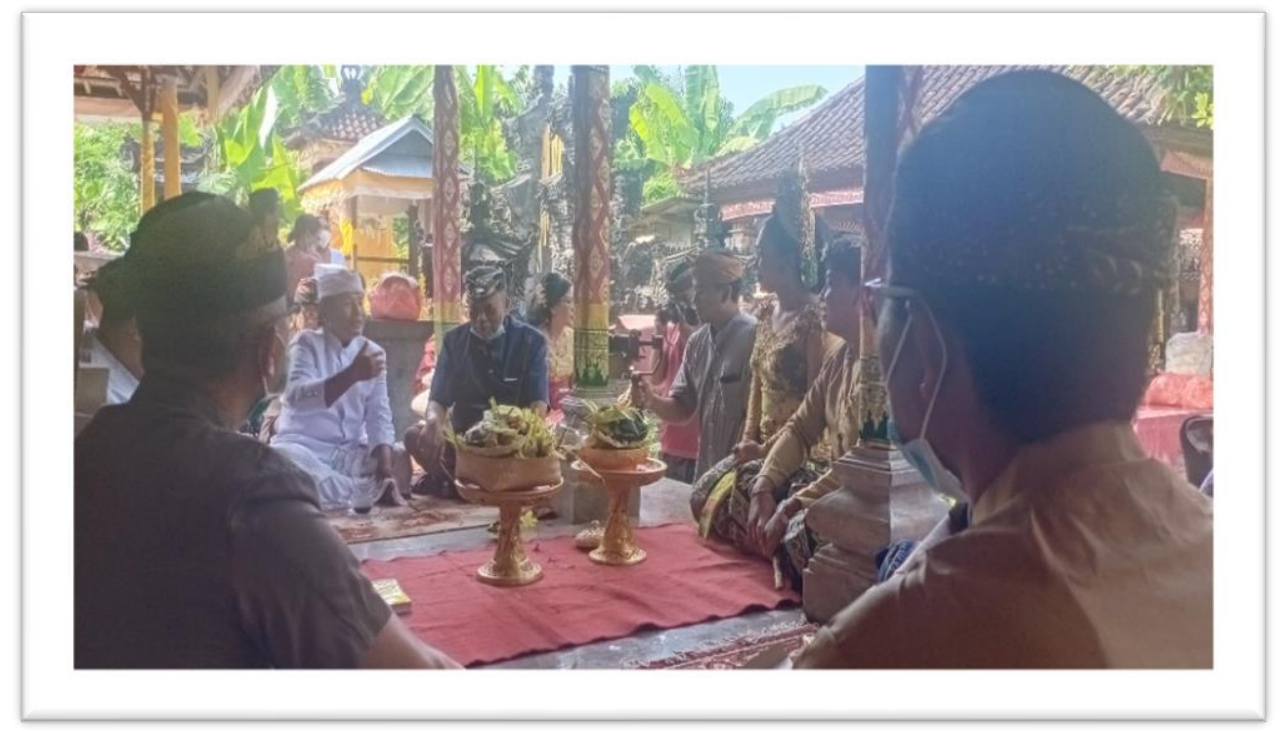

Photo.3.2 Tri Upasaksi concept in Mareraosanoral tradition

GekDiahDesiSentana's Personal Documentation (2021)

So it can actually be said that this mareraosan ceremony has a social meaning by presenting tri upasaksi which is the existence of the tri hitakarana concept. Because of the relationship between humans and humans, namely human witnesses, the relationship between humans and the natural environment is in the understanding of bhuta witnesses, while humans and God are in the meaning of the witness gods. 


\section{CONCLUSION}

Everyone who will carry out a marriage must be aware of the meaning of marriage itself. Marriage is an inner and outer bond between a man and a woman as husband and wife with the aim of forming a happy and eternal family (household) based on God Almighty (Law No. 1 of 1974).The inner and outer bond between a man and a woman deserves the blessing or permission of their parents. This is to avoid the occurrence of estrangement after living a married life. Therefore, in traditional Balinese marriages, parents or families of both parties play a role. The man's family (purusa) proposes to a daughter (pradhana) to be married by the son of a man's family (purusa).

The mareraosan oral tradition is a spoken tradition that still survives in Bali today. This tradition is part of the wedding ceremony in Bali. If a marriage has not passed this tradition, then the marriage is not considered valid. This tradition is very unique, because there are three main witnesses in the mareraosan tradition, namely the witness god, the witness human, and the witness bhuta. When the mareraosantradition takes place, the jururaos and parents will give advice about the nature of being a married couple. Especially married couples in Bali, because the responsibility is not only on the family but also on the community.

\section{REFERENCES}

[1] Mantra, Ida Bagus. (2013). Tata Susila Hindu Dharma. Bali: Udayana University Press.

[2] Ong, Walter J. (2002). Orality and Literacy. New York: Routledge.

[3] Pudentia, MPSS. (2015). Metodologi Kajian Tradisi Lisan. Jakarta: Yayasan Pustaka Obor Indonesia.

[4] Ratna, I NyomanKutha. (2010). Metodologi Penelitian Kajian Budayadan Ilmu Sosial Sosial Pada Umumnya. Jakarta: PT Gramedia

[5] Sudarsana, Ida BagusPutu. (2002). Ajaran Agama Hindu" Makna Upacara Perkawinan Hindu". Denpasar: Percetakan Bali.

[6] Surayin, Ida AyuPutu. (2004). Seri I Upakara Yadnya: Melangkahke Arah Persiapan Upakara Upacara Yadnya. Surabaya: Paramita.

[7] Turner, Bryan S. (2012). Teori Sastradari Klasik Sampai Postmodern. Yogyakarta: Pustaka Pelajar.

[8] Warna, I Wayan. 1990. Kamus Bali-Indonesia. Denpasar: Dinas Pendidikan Dasar Prov. Dati I Bali. 